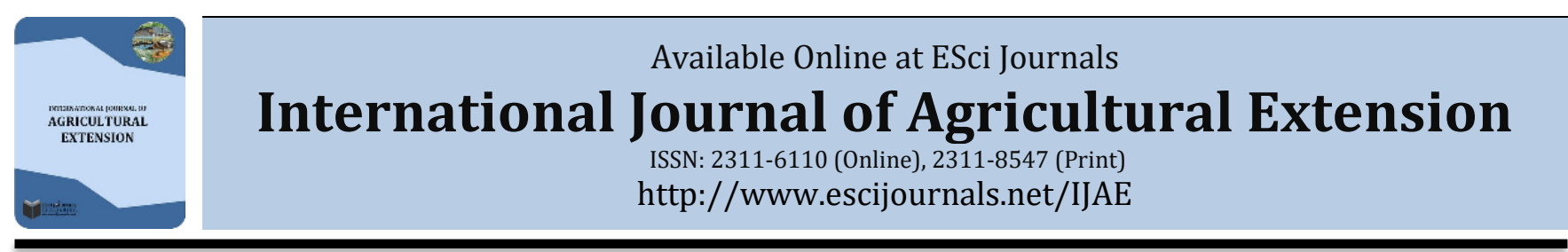

\title{
BENEFITS OF SOCIAL TIES IN FARMER GROUPS AT AGRICULTURAL EXTENSION PLANNING IN THE DISTRICT OF LIMA PULUH KOTA, INDONESIA
}

\author{
aMuhamad Reza*, bMelinda Noer, cYonariza, Asmawi \\ a Agricultural Sciences Study Program, Postgraduate Program, Andalas University, Padang City, West Sumatra, Indonesia. \\ ${ }^{b}$ Socio-economic Agriculture Department, Faculty of Agriculture, Andalas University, Padang City, West Sumatra, Indonesia. \\ c Communication Studies Department, Faculty of Social Science and Political Science, Andalas University, Padang City, West \\ Sumatra, Indonesia.
}

\begin{abstract}
A B S T R A C T
Social ties is an important form of social capital in community groups, including farmer groups, because it will determine the activity of the group. Social ties can be formed based on the connection between ancestry and nonancestry relationships. This article examines the benefits of the farmer group social ties in the agricultural extension planning process in Kabupaten Lima Puluh Kota, a case study of farmer groups at the village level (nagari). The research design used is mixed methods research, that is a combination of qualitative and quantitative methods simultaneously with the weight of the method more pressed on qualitative methods. The type of the research used is case study. Three villages as the locations of this case study are Nagari Balai Panjang, Tanjuang Gadang and Batu Balang Kabupaten Lima Puluh Kota. Site selection was done purposively, with the reason that farmer groups in the three nagari have social bonding based on the connection between ancestry and non-ancestry relationships. Data collection techniques are interviews, questionnaires, documentation, and observation. Data were obtained from key informants from the leader of farmer groups as many as thirteen (13) people and agricultural extension workers as many as three (3) people with snowball techniques. Data ware analyzed by qualitative descriptive techniques using data interpretation analysis tools, and quantitative data is analyzed by scoring techniques using the Arnstein participation ladder. The result of the research proves that social ties of the farmer group play a role as a mobilizer of the participation of the group members in improving the village level agricultural planning process (nagari). The participation level of farmers in the village (nagari) of study cases is at tokenism level up to citizen power for each stage of composing agricultural extension program.
\end{abstract}

Keywords: Participation, citizen power, extension workers, nagari, social capital

\section{INTRODUCTION}

Since the implementation of agriculture extension revitalization in Indonesia, farmers' participation is the main requirement in the process of drafting agricultural extension program. Farmers are positioned as agricultural extension co-workers to establish the decision of the agricultural extension program plan. Some developing countries such as Nigeria and India (Koledoye et al., 2013; Babu et al., 2013) do the same with the Indonesian government. Governments in Tunisia State also recognize the importance of agricultural extension to help promote agricultural

* Corresponding Author:

Email: rezamsi@yahoo.co.id

(C) 2018 ESci Journals Publishing. All rights reserved. development (Thabet et al., 2015). However, not all developing countries provide space for participation to farmers in agricultural extension activities, as found in Iran (Aref, 2011).

In 2006 through Law No. 16 and reaffirmed by Regulation of the Minister of Agriculture No. 25 of 2009, the drafting of agricultural extension program is done by participatory planning approach. As did the Limpopo Provincial Government in South Africa from 1998 to 2006 applying a participatory agricultural education approach (Zwane et al., 2015). Participatory planning is the result of the development of the paradigm of communicative turn in planning popularized by Healey in 1987. The paradigm emphasizes the importance of community participation to produce more development 
planning (Masik, 2005). Since then, the social aspect has become an important component of the development planning process, including social capital (Friedman, 1987).

The form of social capital in this study is the network (Putnam, 1993, Woolcock, 2000) that can encourage cooperation (Fukuyama, 2001) and become adhesive bonds between individuals (Dasgupta \& Sarageldin, 2000) in farmer groups. Individual bonds or social ties are one of the dimensions of networks owned by farmer groups in the village (nagari) of study cases. According to Reza et al. (2016), the bond is formed by the connection between ancestry (saparuik, sasuku, sapusako) and non-ancestry relationships (friendly friendship, urang sumando).

The social ties in farmer groups are expected to be a solution to improve farmer participation in the village level agricultural planning process (nagari) in the District of Lima Puluh Kota. One of the causes of their low participation is because they have not grown farmers' awareness to engage in agricultural extension planning activities (Reza, 2016). Similar conditions were also found by Anis et al. (2014) in Tapada'a Village, Central Suwawa District. Farmer participation in agriculture extension planning process cannot grow by itself. Their participation can be grown by outsiders or from within groups and themselves. According to Egam \& Rengkung (2014), family bonding within community groups is able to encourage their members to participate in the regional planning process in Sub-District of Malalayang. This finding is reinforced by Nasution (2002) stating that the participation of members in group activities because of the ties formed by kinship, friendship, religious equality, the application of norms, values, similarities of fate and similarity of a tribe. Farmer participation can also be well established if the government makes a policy in the field of agricultural extension to increase the capacity of farmers (Ong'ayo et al., 2016).

Social ties in community group are not always able to improve the participation of their members. As Nisha \& Asokhan (2016) discovered in the Nilgiris Tamil Nadu, the social capital that develops in the life of the community is a barrier to women's groups participating in several development programs. The finding is in line with the statement by Rustiadi et al (2011) that the bonding community has such weaknesses as the strong distinction between "our people" and outsiders; there is only one alternative answer; difficult to accept the flow of change; less accommodative to outsiders, but they give priority to the interests of the group.

The theories and previous studies above do not explain why social ties can improve or hinder community participation in planning. Therefore, it is necessary to conduct research with the objective of studying the benefits of social ties of farmer groups in the village level agricultural planning process (nagari). The findings of this study can add knowledge to the theory of planning with the paradigm of communicative turn in planning, especially participatory planning through increased participation of group members by social ties.

\section{MATERIALS AND METHODS}

The design of this research is mixed methods research using concurrent embedded strategy model which is the strengthening mix/second method reinforces the first method (Creswell, 2009). This type of research is a case study. The study was conducted from April to October 2016. Three villages selected as research sites were Nagari Balai Panjang, Tanjuang Gadang and Batu Balang, District of Lima Puluh Kota. Primary data were obtained from key informants consisting of 13 farmer group leaders and 3 extension workers with snowball technique. Farmer groups have 25 members. The focus of this research data is the benefit of social ties in farmer groups seen from the level of farmer participation and improvements generated in agriculture extension planning process at village (nagari) level. Qualitative data were analysed using qualitative descriptive technique through the interactive model (Miles \& Huberman, 1992) with data interpretation analysis tools. Quantitative data were analysed by scoring method (see Table 1). The results of the scores obtained were incorporated into the Arnstein participation ladder (1969).

\section{RESULTS AND DISCUSSION}

Social Ties of Farmer Groups as Activator of Farmer's Participation in Improvement of Agricultural Counseling Planning Process at Village (Nagari) Level. The villagelevel agricultural extension planning process (nagari) is carried out through several interrelated stages. There are 7 (seven) activities requiring farmers' participation to produce an agricultural extension program plan. The results of this study find the participation of farmers from farmer groups who have social ties on 6 (six) activities are on the ladder of consultation to the level of citizen power (Figure 1). 
Table 1. Interval Class for Measuring Farmers Participation Rate in Village (Nagari) agricultural extension planning process.

\begin{tabular}{lll}
\hline No & Interval Class & Participation Level \\
1. & Ladder 1 (manipulation ) $=52$ to $\leq 97,5$ & No participation of farmers. \\
2. & Ladder 2 (theraphy) $=97,5$ to $\leq 143$ & \\
3. & Ladder 3 (informing) $=143$ to $\leq 188,5$ & False participation level (tokenism) \\
4. & Ladder 4 (consultation) $=188,5$ to $\leq 234$ & \\
5. & Ladder 5 (placation) $=234$ to $\leq 279,5$ & \\
6. & Ladder 6 (partnership) $=279,5$ to $\leq 325$ & Level of Citizen Power (citizen power) \\
7. & Ladder 7 (delegated power) $=325$ to $\leq 370,5$ & \\
8. & Ladder 8 (citizen control) $=370,5$ to 416 & \\
\hline
\end{tabular}

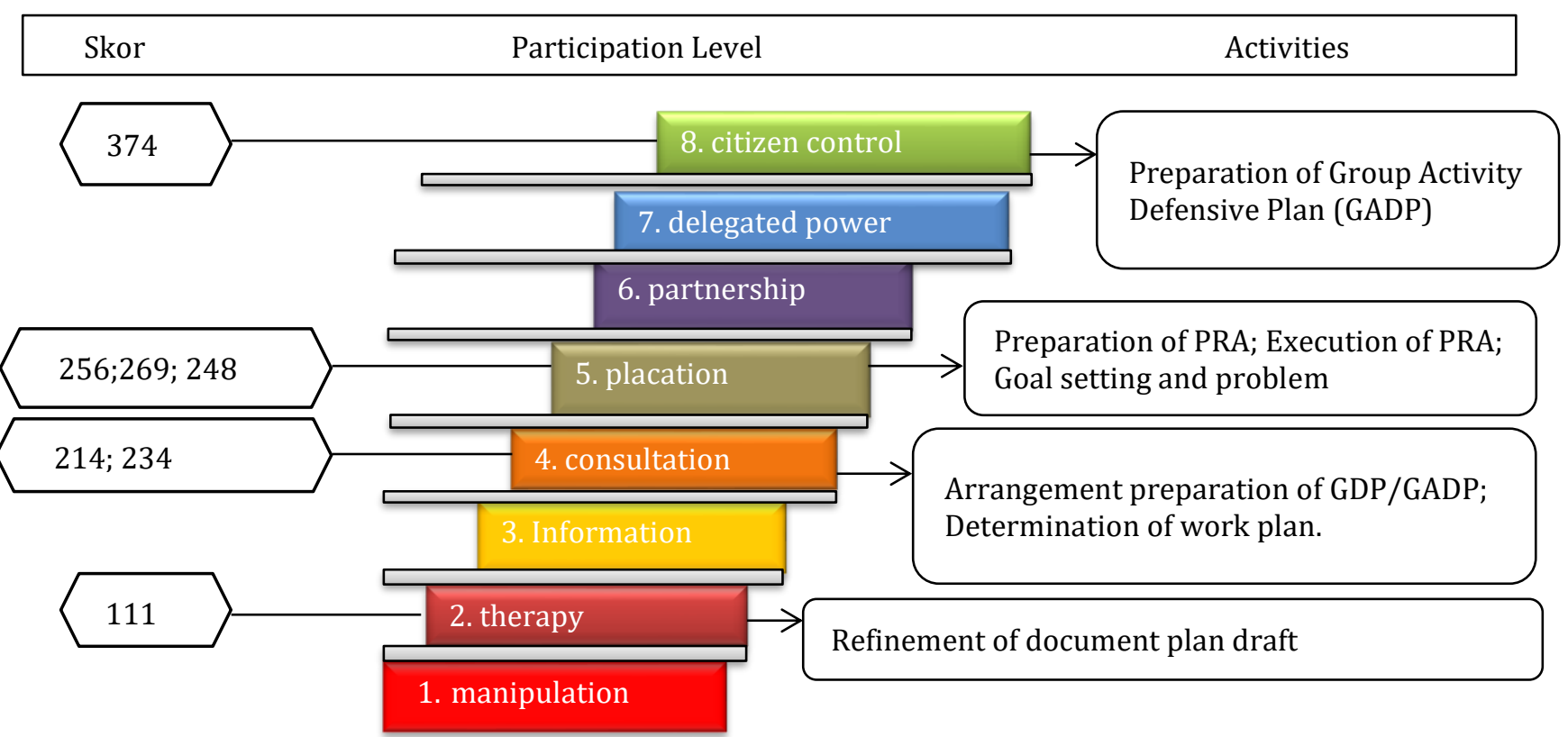

Figure 1. Participation level of farmers groups that has Social tiers in Process of Village Farming Counselling Planning in Case Study Site.

The farmer participation rate in Figure 1 was obtained from the assessment given by 13 heads of farmer-based on the connection between ancestry and non-ancestry relationships farm groups at the case study sites. The highest participation of farmers in the village level agricultural planning process is in the Activity of the Group Activity Defense Scheme with a score of 374. In those activities, more than $90 \%$ of the members of the blood-clad and blood-stuck bonded farmer group play an active role in drawing up the Definitive Plan of Group Activity. Therefore, their level of participation is at the level of citizen power.

In Participatory Rural Appraisal (PRA) preparation activities, PRA implementation, and goal setting and problems, farmers' participation is at the ladder of placation participation, which means it is at tokenism level with participation scores of 256, 269 and 248 respectively. In preparatory activities the Group Defensible Plan (GDP)/Group Activity Defensive Plan (GADP) and the establishment of agricultural extension work plan, the participation is at tokenism level with the participation score of 214 and 234 respectively. The total activities are tokenism level involves the representation of farmer group that is the leader of farmer groups as many as thirteen (13) peoples. The condition of participation level is not high because the decision in each activity is still dominated by agricultural extension workers.

The lowest level of participation is in the improvement of the draft of the village level agricultural planning document (nagari) that is at the level of no participation. This condition is caused by the leader of the farmer 
group as the representative of the farmers only serves as a giver of input to the agricultural extension, while the main actor is making the decision of agricultural extension workers. Their participation is visible with time (attendance), energy, information, food/drink donations and decision making. Although the condition of farmer participation is quite different, farmer involvement has been considered by agricultural extension workers in preparing village (nagari) level agricultural extension program. The conditions above prove the concept of community participation which states that participation is a manifestation of awareness and concern, and also responsibility (Theresia \& Toto, 2014) of the peasant community on the cultivation of agricultural extension planning to produce program plans that meet the needs of farmers. Furthermore, Uphoff, Cohen \& Goldsmith (1979) and Madrie (1986) argue that community participation is a mental and emotional engagement consciously engaged in activities in a group life, or a community in society. Even the form of farmer-given participation in the village(nagari)-level agricultural extension planning process is similar to Sutami's statement in Koampa et al (2015).

The participation of farmers in the agricultural extension planning process is influenced by the social ties within the farmer group. Key informant farmers acknowledge that their social ties are formed by the connection between ancestry (saparuik, sasuku, sapusako) and nonancestry relationships (friendship, urang sumando). The bonds move them to be involved in every activity related to the preparation of the agricultural extension program plan. The Figure 2 below illustrates how social ties works within farmer groups mobilize the participation of their members.

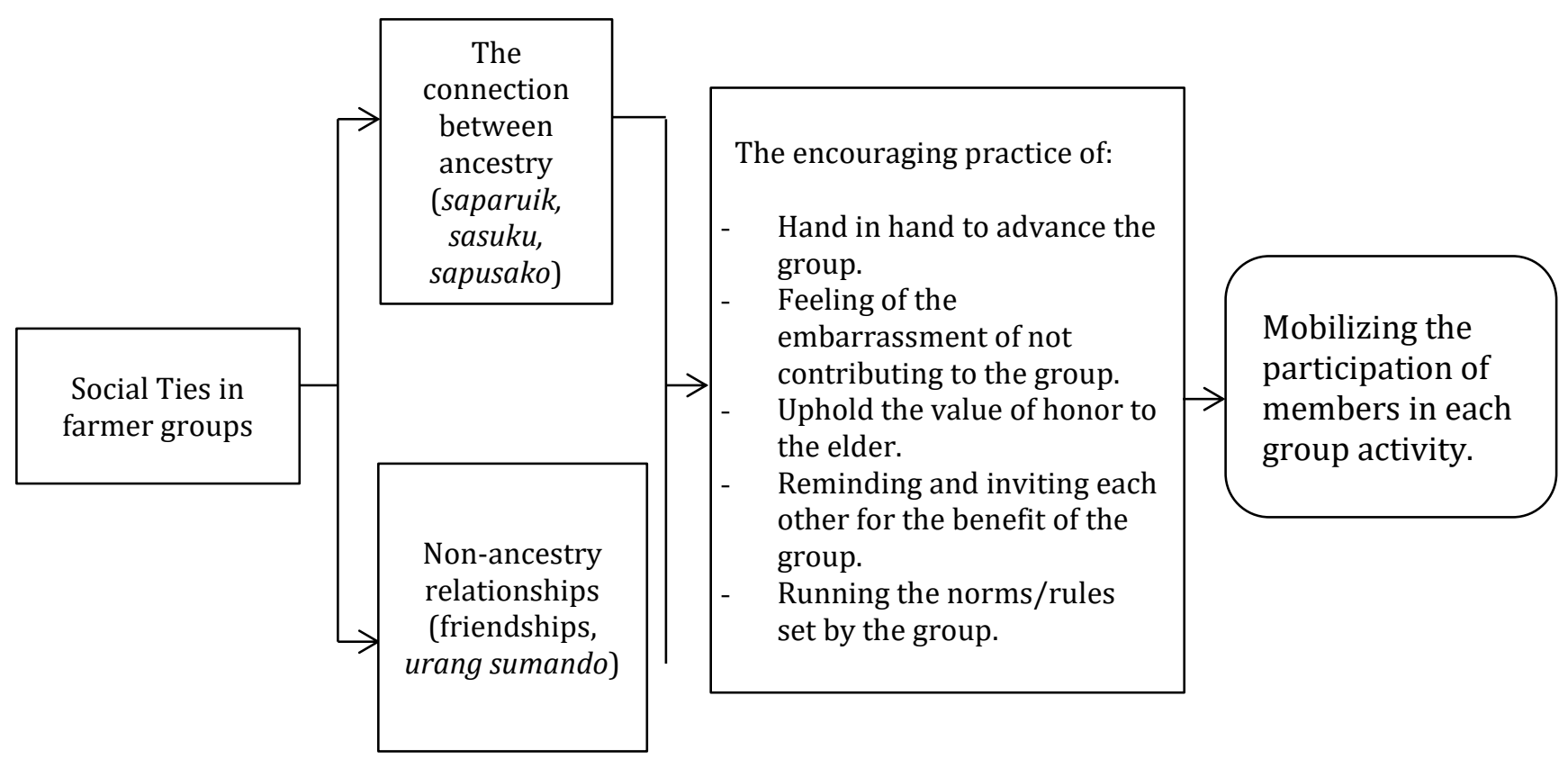

Figure 2. Illustration of How Social Ties Works in Farmer Group to Move Member Participation in Case Study Site.

The above findings prove that social ties within farmer groups have benefits to improve farmers' participation, especially in the village level extension planning process at the case study sites. This research denies negative statements about the bonding of social capital such the social ties of several theories that have been popular so far (Putnam, 1993; Hasbullah, 2006; Rustiadi \& et al., 2011). It is proven that social ties do not become obstacles in the village-level agricultural extension planning process, farmers in farmer groups who have social bonds open to change, even the values and norms prevailing in the group do not benefit a certain hierarchy and feudal level. The results obtained from this study further support the concept that bonding capital, in this case, social ties can make members of the group interacted actively, have mutual support and mutual trust for the interests of the group (Woolcock, 2000; Darcy et al. 2014). One of the relationships that make up their bonds is the tribal equality that also encourages group members to be involved in group activities. This condition is similar to that found by Narayanan and Anilkumar (2016) that a peasant group having tribal 
similarities in India has a better participation when compared with farmer groups that do not have tribal similarities.

Implications of Benefits of Social Ties in Farmer Groups in the Agricultural Counseling Planning Process at the Village Level: The consequence of the benefits of social ties in farmer groups to improve farmer participation in counseling planning at village level is the occurrence of process improvement undertaken by agricultural extension workers in Agricultural Extension Working Areas (AEWA). Based on the data in Table 1, it can be seen that the 7 (seven) activities undertaken in the village(nagari)-level farm planning process involve farmers in the preparation, implementation and decision-making steps of the planning. All phases are implemented based on Regulation of the Ministry of Agriculture No. 25 of 2009 About Agricultural Counseling Program. It means that, farmers' participation generated by social ties within farmer groups is able to assist agricultural extensionists to adopt a participatory approach to draft a village agriculture counseling program.

The workings of social bonds in farmer groups to improve the process of agricultural counseling planning are the ties in the form of connection between ancestry (saparuik, sasuku, sapusako) and non-ancestry relationships (friendship, urang sumando) to encourage members of farmer groups to invite each other, remind others to be involved in this activity. Particularly, the habits to invite and remind group members performed by figures in groups such as chair of the group, group organizers or datuak and mamak in groups. It makes members feel embarrassed if they cannot attend a meeting that has been reminded by group leaders. In addition, group members recognize that their presence and activity in agricultural counseling planning activities impact to their profits and groups. More details can be seen in the following Table 2.

Table 2. Improvement of Agricultural Awareness Planning Process Through Social Ties in Farmer Groups in Case Study Sites of the District of Lima Puluh Kota.

\begin{tabular}{lll}
\hline No & Stages & Activities Implemented \\
\hline 1. & Determination & a) Excavation of village \\
& of & data and information; b) \\
& Circumstances & Arrangement of RDKK
\end{tabular}

2. Setting goals a) Setting goal; b) Setting and problems problems/obstacles faced to reach the goals.

$\begin{array}{ll}\text { How the Bonding Works } & \text { Way of Improving } \\ \begin{array}{l}\text { Connection between } \\ \text { ancestry }\end{array} \begin{array}{l}\text { Farmers participation } \\ \text { sasuku, sapusako) and }\end{array} & \begin{array}{l}\text { Farmers as data and } \\ \text { information source }\end{array} \\ \begin{array}{l}\text { non-ancestry } \\ \text { relationships (friendship, }\end{array} & \begin{array}{l}\text { Decision of GADP set by the } \\ \text { farmers }\end{array} \\ \text { urang sumando) } & \text { Farmers participation } \\ \text { encourage farmer groups } & \text { The occurrence of input from } \\ \text { to invite each other, } & \text { farmers. } \\ \text { reminding other } & \text { Goal setting decisions are taken } \\ \text { members to get involved } & \text { by mutual agreement } \\ \text { in this activity. } & \text { Farmers participation } \\ & \text { The occurrence of the input } \\ \text { process. } & \text { Planning decisions are taken by } \\ & \text { mutual agreement. }\end{array}$

3. Establishment Capture the input and of the Village agree on the Village Agricultural Agricultural Counseling Counseling Activity Plans Activity Plan mutual agreement.

Source: Resume of the interview, 2016.

The improvement of agricultural counseling planning process at village(nagari) level generated by social bonds within farmer groups are:

1. The participation of farmers in every stage of planning.

2. Farmers become a source of information and data for planning needs.

3. There has been interaction and dialogue between farmers and agricultural counseling workers in every stage and planning decisions are not absolutely determined by agricultural extension workers or there is an opportunity for farmers to decide on planning decisions.

This finding is in line with the expectations of the government to establish the use of a participatory approach to drafting a village-level agricultural counseling program (Ministry of Agriculture, 2009; Dirlanudin, 2011).

The conditions above are similar to those of Liang et al. (2015) which suggest that there is a positive 
relationship between certain dimensions of social capital and the participation of members in training and general meetings in a cooperative in China. Similarly, Herforth et al. (2015) find that farmers' social networks are crucial determinants of participating in modern supply chains in environments characterized by a homogeneous agricultural sector in the Andes of Ecuador. Both of these studies prove that social capital is able to improve public participation both in cases of cooperative institutions and inhibited supply chain activities. Although the case differs from the case expressed in this paper, the substance of social capital capabilities to improve participation are equally revealed in both studies.

The results of this study can show that social ties found in community groups (farmer groups) with good community culture, can be an alternative solution for farmer participation improvement. In particular, it can be used to assist in the implementation of agricultural counseling activities especially in the application of participatory approaches. In this case, agricultural extension workers in other villages in the District of Lima Puluh Kota can utilize social bonds in farmer groups so that the problems of farmers' participation in village(nagari) level agricultural counseling planning process can be solved well.

\section{CONCLUSION}

The social ties within the farmer groups found in case study sites are able to mobilize farmers' participation in the village(nagari)-level agricultural extension planning process. Proven from their participation they are at tokenism level until the citizen power in every stage of the arrangement of agricultural extension program plan. The social ties in the farmer groups formed by the connection between ancestry (saparuik, sasuku, sapusako) and non-ancestry relationships (friendship, urang sumando) encourage farmers to practice: 1) hand in hand to advance the group, 2) shame for not contributing to the group, 3) uphold the value of respect to the elder, 4) remind each other and invite for the benefit of the group and 5) run the norms/ rules set by the group. The action resulting in the participation of farmers in order to improve the village (nagari) level agricultural extension planning process. Proven by the involvement of farmers in every stage of extension planning, farmers become a source of information and data, interaction and dialogue between farmers with agricultural extension, and planning decisions communicated with farmers.

\section{ACKNOWLEDGEMENT}

I would like to thank Kementerian Ristekdikti for helping me to fund the research through doctoral dissertation research grant. To my advisor, Prof. Dr. Ir. Melinda Noer M.Sc., Prof. Dr. Ir. Yonariza, M.Sc., Dr. Asmawi, MS., who have contributed me with valuable input and knowledge until I complete this study. I would like to thank all the academic staff of UNAND Graduate Program who have helped in completing the funding administration of this research. I would also like to thank the entire research informants who have been willing to spend their time and provide me with information and data for my analysis. Last but not least, this acknowledgment goes to those who have helped me smoothening in term of administration and easing the research.

\section{REFERENCES}

Anis, M.S., Effendy, L., Muslihat, J.E . (2014). Partisipasi Anggota Kelompok Tani Dalam Penyusunan Rencana Defenitif Kelompok/ Rencana Defenitif Kebutuhan Kelompok. Jurnal Penyuluhan Pertanian, 9, 37-42.

Aref, F. (2011). Farmers' participation in agricultural development: The case of Fars province, Iran. Indian Journal of Science and Technology, 4, 155158.

Arnstein, S.R. (1969). A Ladder of Citizen Participation. JAIP, 35 (4), 216-224.

Babu, C.S., Joshi, P.K., Glendenning,J.C., Asenso-Okyere, K\& Sulaiman, R. (2013). The State of Agricultural Extension Reforms in India:Strategic Priorities and Policy Options. Agricultural Economics Research Review,26 (2), 159-172.

Creswell, J.W. (2009). Research Design Quantitative, Qualitative, and Mixed Methods Approaches. Los Angeles: Sage Publications.

Darcy, S., Maxwell, H., Edwards, M., Onyx, J., Sherker, S. (2014). More than a sport and volunteer organisation: Investigating social capital development in a sporting organisation. Sport Management Review, 257. journal homepage: www.elsevier.com/locate/smr.

Dasgupta, P \& I. Sarageldin, editor. (2000). Social Capital: a multi-faceted perspective. World Bank, Washinton, D.C.

Dirlanudin. (2011). Perencanaan Program Penyuluhan Kewirausahaan (Pada Pengusaha Mikro Industri Garmen di Kelurahan Sukawana Kabupaten 
Serang Provinsi Banten). Jurnal Ilmiah Niagara, 2 (1), 81-106.

Egam, P.P \& Rengkung, M.M. (2014). Perencanaan Kota: Keberlanjutan Ethnic CommunityBerbasis Partisipasi Masyarakat Lokal. Media Matrasain, 11(3), 15-23.

Friedmann, J. (1987). Planing in the public Domain: From Knowledge to action. Princeton. Princeton Univ. Press.

Fukuyama, F. (2002). The Great Disruption: Hakikat Manusia dan Rekonstitusi Tatanan Sosial.CV Qalam, Yogyakarta.

Hasbullah, J. (2006). Sosial Kapital: Menuju Keunggulan Budaya Manusia Indonesia. MR-United Press, Jakarta.

Herforth, N.,Theuvsen, L.,Vásquez, W \& Wollni, M. (2015). Understanding participation in modern supply chains under a social network perspective - evidence from blackberry farmers in the Ecuadorian Andes. Global Food Discussion Papers No.57.

Koampa, V.M., Benu, O.L.S, Martha, M.S. \&Vicky, R.B.M. (2015). Partisipasi Kelompok Tani Dalam Kegiatan Penyuluhan Pertanian di Desa Kanonang Lima, Kecamatan Kawangkoan Barat. Jurnal ASE, 11 (3A), 19-32.

Koledoye, F.G., Deji, F.O., Owombo, T.P\& Olofinniyi, O.E. (2013). Evaluation in agricultural extension: A philosophical Approach. Journal of Agricultural Extension and Rural Development, 5 (1), 1-7.

Liang,Q., Huang, Z., Lu, H., \& Wang. (2015). Social Capital, Member Participation, and Cooperative Performance: Evidence from China's Zhejiang. International Food and Agribusiness Management Review, 18(1), 49-78.

Madrie. (1986). Beberapa Faktor Penentu Partisipasi Anggota Masyarakat Dalam Pembangunan Pedesaan. diss., Institut Pertanian Bogor.

Masik, A. (2005). Hubungan Modal Sosial dan Perencanaan. Jurnal Perencanaan Wilayah dan Kota, 16 (3), 1-23.

Miles, Mathew. B, \& Huberman A.M. (1992). Analisis Data Kualitatif; Buku Sumber Tentang MetodeMetode Baru (Penerjemah Tjetjep Rohendi Rohidi). UI-Press. Jakarta.

Ministry of Agriculture. (2009). Peraturan Menteri Pertanian Nomor: 25/Permentan /OT.140/5/2009 Tentang Pedoman Penyusunan
Programa Penyuluhan Pertanian.

Narayanan, V.M.P \& Anilkumar, A. (2016). Work Participation in Cultural Operations of Rice Farming by Tribal and Non-Tribal labourers in Wayanad district: A Comparative Analysis. Journal of Extension Education, 28 (4).

Nasution, A. (2002). Ikatan Primodial Dalam Kegiatan Bisnis Orang Minangkabau Di Sukaramai Medan. digitized by USU digital library.

Nisha, R \& Asokhan, M. (2016). Improving the Participation of Tribal Women in Developmental Programmes. Journal of Extension Education, 28 (4).

Ong'ayo, A.H.,Onyango, C.A., Ochola, W.W. (2016). SmallScale Farmers' Perceptions Towards Demand Driven System of Agricultural Extension Service Delivery. Case Study of Siaya and Kilifi Counties In Kenya. Int. J. Agr. Ext. 04 (01) 2016. 01-09.

Putnam, R.D. (1993). The Prosperous Community: Social Capital and Public Life. American Prospect, 13, Spring, 35- 42. In Elinor Ostrom \& T.K. Ahn. 2003. Foundation of Social Capital. Massachusetts: Edward Elgar Publishing Ltd.

Reza, M. (2016). Proses Perencanaan Program Penyuluhan Pertanian Tingkat Nagari di Kabupaten Lima Puluh Kota. Jurnal Menara Ilmu, 10 (63).

Reza, M., Noer, M., Yonariza, Asmawi. (2016). Kelompok Ikatan Sesama Petani dalam Proses Perencanaan Penyuluhan Pertanian Tingkat Nagari di Kabupaten Lima Puluh Kota Studi Kasus Nagari Balai Panjang dan Tanjuang Gadang. Prosiding Seminar Nasional Fakultas Pertanian UNTIRTA Serang 2 November 2016, 152-161.

Rustiadi, E.,Saefulhakim,S. \& Panuju, R.D. (2011). Perencanaan dan Pengembangan Wilayah.Crestpent Press dan Yayasan Pustaka obor Indonesia. Jakarta.

Thabet, B., Dhehibi, B., Kassam, S., Aw-Hassan, A. (2015). Good Intensions And Hard Realities: Achievements And Challenges In Agricultural Extension Systems In Tunisia. Int. J. Agr. Ext. 03 (03) 2015. 209-216.

Theresia, A \& Toto. (2014). Pembangunan Berbasis Masyarakat Acuan Bagi Praktisi, Akademis, dan Pemerhati Pengembangan Masyarakat. Alfabeta. Bandung.

Uphoff, N.T., John M. Cohen \& A.M. Goldsmith. (1979). 
Rural Development Committee: Feasibility and Aplication of Rural Development Participation: A State of the Art Paper. Cornell University. Ithaca. New York.

Woolcock, M. (2000). Why should we care about social capital? Canbera Bulletin of Public Adminitrations, 98, 17-19.
Zwane, E.M., Niekerk, V.J., Groenewald, I. (2015). Does Particpation In Agriculture Improve Output: An Experience From Limpopo's Broadening Agricultural Services And Extension Delivery (Based) Programme. Int. J. Agr. Ext. 03 (02) 2015. 83-92. 